\title{
Entrevista Profa. Dra. Marta Heloisa lopes
}

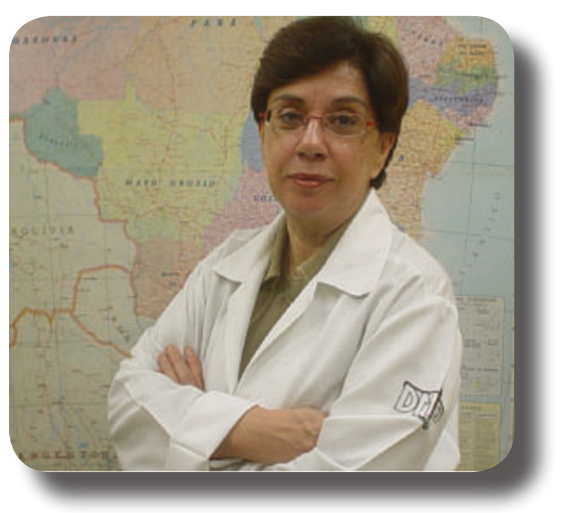

RM: Olá Dra. Marta, para começarmos a entrevista, gostaria que a senhora fizesse uma introdução para elucidar melhor esta nova gripe, Influenza A (H1N1), também conhecida como gripe suína.

Dra. Marta: Para entender melhor esta nova gripe, como você chamou, vou antes explicar o que é a influenza sazonal. O vírus influenza é responsável por infecções de vias aéreas superiores, o que podemos chamar de gripe; mas no Brasil chamamos qualquer infecção de vias aéreas superiores de gripe. E nem todas são infecções causada pelo vírus influenza. Tem-se o vírus sincicial respiratório, adenovírus, rinovírus e muitos outros que circulam mais ou menos por essa época do ano, causando infecção de trato aéreo superior, e a gente acaba confundindo e chamando tudo de gripe.

Os vírus Influenza são responsáveis por infecção de vias aéreas superiores, que causam febre, mal-estar, mialgia, além de tosse, coriza, secreção, etc. Influenza é uma doença relativamente grave, sempre foi, é uma doença que acomete principalmente a população nos extremos da vida - idosos e crianças pequenas - ela pode até ser fatal Os vírus influenza são sazonais, ou seja, eles circulam predominantemente no inverno, nas regiões de clima temperado. Então, nos países ou regiões que têm as estações do ano bem definidas, você tem maior circulação dos vírus Influenza nos meses de inverno. Similar ao que ocorre nas regiões sul e sudeste do Brasil, onde temos estações mais bem definidas que no norte e nordeste brasileiros, ainda que não tenhamos estações tão bem definidas como no Hemisfério Norte. Assim, todo ano, nós temos realmente casos mais frequentes e mais graves, principalmente nesta época do ano, em pacientes nos extremos da vida e em pacientes imunodeprimidos.

Os vírus Influenza podem levar a óbito por causar uma pneumonite intersticial, ou podem diminuir as defesas do organismo, criando uma porta para a entrada de bactérias. Você por acaso já ouviu falar "um indivíduo teve uma gripe mal curada e desenvolveu uma pneumonia"? Essa é a forma popular de descrever o que acontece. Na verdade a gripe serviu de porta de entrada para uma infecção bacteriana. $E$ isso pode ocorrer todo ano no inverno, é a Influenza sazonal.

Os vírus influenza são vírus de RNA e têm uma grande capacidade de mutação, então os vírus que circulam em um ano podem ser bem diferentes do que circulam em outro, predominantemente no inverno. Estas mutações pontuais são chamadas drifts. Os vírus influenza têm proteínas em sua superfície, as Hemaglutininas e as Neuroaminidases, segundo as quais são classificados em H1N1 (H3N2, H5N1, etc.). Existem anticorpos contra o vírus influenza, mas o fato de ele mudar constantemente faz com que estes anticorpos se tornem ineficientes.

O habitat natural dos vírus influenza são as aves. Existem muitos subtipos de vírus influenza, mas apenas alguns deles são patogênicos ao homem. Vírus das aves podem sofres uma grande mutação (shift) e tornar-se o capaz de infectar o homem e então ser transmitido de homem a homem. Os vírus aviários podem sofrer essa grande mutação (shift) e 
passar da ave para o humano, ou podem se recombinar com vírus de outros animais ou do homem, no porco, e sofrer um rearranjo genético, dando origem a um novo vírus, como aconteceu com o H1N1.

No caso da gripe $A$, nenhum homem teve contato prévio com esse novo vírus, então ninguém tem anticorpos contra ele, ou seja, todos estão suscetíveis, o que leva a uma pandemia. Que é diferente das epidemias sazonais, que ocorrem todo ano e podem diferir na sua intensidade de ano para ano, a depender do vírus circulante. Nessa situação, o vírus é desconhecido pela espécie humana, e, se este vírus se propagar rapidamente, se ele tiver uma alta virulência causa uma doença grave. Foi o que aconteceu em 1918, com a pandemia de gripe espanhola. Era um H1N1 também. É o que aconteceu em 1957, com a gripe asiática, e o que aconteceu em 1968, com a gripe de Hong Kong. Elas foram pandemias que causaram grande número de doentes, alta morbidade e alta mortalidade. Por que isso? Porque ninguém tinha memória imunológica contra esses vírus.

RM: Qual o papel da vacinação na contenção de uma pandemia?

Dra. Marta: A chance de você começar a dar remédio e esse vírus influenza, que sofre muita mutação, rapidamente se tornar resistente à droga antiviral é um problema seríssimo. Então qual é a saída pra você conter uma grande pandemia? É vacina. Porém, a vacina só pode ser feita a partir do momento em que você identifica o vírus que vai causar a pandemia. A partir desse momento você tem que isolar o vírus no laboratório, cultivar o vírus no laboratório, atenuar o vírus, inativá-lo, porque a vacina que nós dispomos é uma vacina de vírus inativados, mesmo havendo vacinas de vírus vivos.

Você precisa de tempo para fazer a vacina, para isolar, cultivar e atenuar o vírus. As vacinas de vírus são cultivadas em cultura de células ou membrana alantóide, de ovo de galinha. Então você precisa ter granjas específicas, onde as aves são criadas sem nenhuma contaminação, para os ovos serem o mais purificados possível. Não adianta fazer ótima vacina que esteja contaminada. É um controle rigoroso de qualidade. Então, o vírus é inativado e depois processado para ser produzido em grande quantidade. Este procedimento leva 6 meses, pelo menos. Se você encurtar esse procedimento, você tem chances de não ter qualidade na produção.

RM: E depois desse tempo de produção, a vacina ainda será útil?

Dra. Marta: Sim. Atualmente, a disseminação do vírus é mais rápida, por causa dos meios de transporte, veja a rapidez: o vírus foi detectado primeiro nos Estados Unidos, na Califórnia, em duas crianças, mas inda não se sabia a importância da situação. Em seguida, muitos casos foram notados no México, foi aí que a gripe chamou a atenção, e em seguida, apareceram novos casos em vários países. Estão sendo fabricadas vacinas. Inclusive aqui mesmo no Instituto Butantã há esforços para a sua produção. vacina?

RM: Como está ocorrendo a produção dessa

Dra. Marta: A OMS trabalha o vírus: coloca o H1N1 em contato com um vírus padrão, de laboratório, e forma um vírus híbrido, cujo RNA é do vírus do laboratório e cuja superfície é a do H1N1. Este vírus híbrido é distribuído pela OMS para os laboratórios do mundo inteiro para que eles produzam a vacina.

RM: Atualmente, o nível de atenção da OMS passou para o nível 6 , de pandemia já estabelecida. Essa escala é preventiva ou mostra a situação atual?

Dra. Marta: A Organização Pan-Americana de Saúde (OPAS) tem vários níveis de alerta. Há muito tempo nós já estávamos no terceiro nível de seis. Já se esperava uma pandemia. Mas se temia o H5N1, o vírus aviário da gripe do frango. A gripe aviária já acontecia, estava matando muitas aves e havia poucos casos em humanos. Então o medo é que o H5N1, que é altamente virulento, sofresse uma transformação e passasse a atingir o homem com conseqüências desastrosas. Então todas as atenções estavam voltadas para o H5N1, e não foi ele o causador da pandemia, mas o H1N1. Este H1N1 parece ser menos virulento que o $\mathrm{H} 5 \mathrm{~N} 1$ e parece não ter um comportamento de grande virulência como era temido no início da pandemia.

Agora estamos no estágio 6 , que significa que há transmissão pessoa a pessoa da doença em pelo menos 2 regiões da OMS. É uma classificação geográfica, é uma pandemia (epidemia global). No começo, o Brasil estava tentando conter a entrada do vírus. Mas, desde julho, o Brasil possui uma transmissão sustentada, ou seja, transmissão de pessoa a pessoa dentro do país e passou a adotar medidas que funcionem para reduzir a transmissão, tal como está ocorrendo.

RM: Sobre as medidas de contenção do vírus que o Brasil tomou, como a senhora analisa seus efeitos?

Dra. Marta: O trabalho brasileiro foi muito bom, conseguimos detectar alguns casos que estavam chegando de países acometidos. Estes casos foram 
isolados, tratados, o diagnóstico foi feito corretamente. No início teve um pequeno atraso de diagnóstico por demora para se obter um primer [iniciador de reações de PCR e RT-PCR, utilizados para diagnosticar o vírus]. Mas assim que chegou, começou a ser utilizado e os diagnósticos foram feitos.

RM: Como você deve ter acompanhado, como coordenadora do curso do $4^{\stackrel{0}{ }}$ ano de Moléstias Infecciosas, tivemos uma paralisação depois do retorno às aulas e voltamos dia 17 de agosto. Gostaria da sua opinião sobre essa decisão do Ministério da Saúde.

Dra. Marta: A decisão foi correta. Ela tem substrato científico para ser tomada. Inclusive, passei para vários alunos um artigo que foi publicado no Lancet Infectious Diseases, mostrando vários panoramas do que se fazer em relação ao fechamento de escolas em situações de epidemias. Nesse artigo fica claro que para que o fechamento das escolas tenha algum impacto, é necessário que essa atitude seja tomada precocemente. Ou seja, o governo tomou essa medida antes que ela não tivesse mais efeito. $\mathrm{E}$, paralelamente a essa medida, foram tomadas várias outras. O conjunto de todas as medidas tomadas pode trazer alguma resposta sobre a eficácia na contenção da pandemia, mas, no momento, é impossível saber cientificamente o impacto de cada uma separadamente.

RM: Você acha que a imprensa foi ajudou ao cobrar medidas governamentais e ao avisar a população sobre a atual gripe, ou não?

Dra. Marta: A cobrar medidas não. O Brasil já faz parte, assim como outros países, desse plano de contenção de uma pandemia de Influenza há muitos anos. Nós estávamos no nível 3, quer dizer, já esperávamos que pudesse aparecer uma pandemia, e o Brasil fazia parte, através da Organização Mundial da Saúde, desse plano de contenção. Então essas medidas já vinham sendo elaboradas. Mesmo porque, da noite pro dia, você não consegue ativar tudo isso. Agora, com relação a avisar a população, eu acho que a mídia teve um bom papel, porque as pessoas ficam sabendo, procuram assistência e divulgam a informação, o que é útil para controle da pandemia. Um pouco alarmista? Tenho a impressão de que o que não tem alarme não rende muita notícia. Mas de um modo geral, no papel de divulgação, eu acho que foi um papel adequado da imprensa.

RM: Como deve ser a postura de um profissional de saúde frente às notícias divulgadas na mídia leiga?

Dra. Marta: Apesar de a imprensa leiga ser um grande meio de informação para os profissionais de saúde, estes devem consultar as informações acadêmicas e científicas, como o que é enviado pela OMS, para falarem com maior propriedade sobre este e outros assuntos.

A Organização Mundial de Saúde, A Secretaria de Saúde do Estado de São Paulo e o Ministério da Saúde do Brasil disponibilizam em seus sites um mapa epidemiológico contendo quantos casos foram diagnosticados, quantos casos foram a óbito, entre outras informações. Os dados oficiais são muito mais precisos que quaisquer outras fontes. Os números de casos são geralmente menores do que os divulgados pela imprensa em geral, porque os dados oficiais esperam a confirmação do caso antes de contabilizar.

RM: Você falou também que o Brasil já vinha se preparando desde a gripe aviária (H5N1). Esse preparo era apenas em relação à contenção?

Dra. Marta: Era focado no plano de contenção de uma pandemia, fosse ela por qual vírus fosse. $O$ Brasil já vinha se articulando para a contenção de uma pandemia. Do ponto de vista de pesquisa, por exemplo, o professor Isaias Raw, no Instituto Butantã, já estava trabalhando com o vírus H5N1.

RM: Uma coisa que me deixou curioso, foi o que você falou sobre terem identificado o vírus inicialmente em duas crianças nos Estados Unidos. Mas os sintomas são exatamente como os de outras gripes. O que faz uma pessoa levantar a possibilidade de haver um vírus novo?

Dra. Marta: Na verdade, não foi o médico que foi atrás do vírus novo, foi o vírus novo que veio atrás de nós. A Dra. Ana Marli pode falar um pouco sobre isso.

Dra. Ana Marli: Há uma vigilância de gripe, colhe-se, rotineiramente, material de pessoas com gripe. Existem alguns locais que fazem isso. Em São Paulo, é o Hospital Menino Jesus que colhe amostras de secreção nasal de pacientes com gripe, 5 amostras por semana pelo menos. Vários hospitais do mundo fazem isso. Após a coleta, esses vírus são isolados e mandados para identificação, justamente para identificar os novos vírus. Na verdade, ninguém pensou que esse vírus fosse novo. Essa vigilância detecta quais são os vírus novos e quais são os mais importantes em termos de circulação, os mais frequentes são os que vão entrar na composição da vacina, que é feita duas vezes por ano, baseada na vigilância dos últimos 6 meses do mundo inteiro. Às vezes, nós estamos usando na nossa vacina um vírus que foi identificado no hemisfério norte, mas por que isso? Porque o vírus da Influenza circula 
muito rapidamente, como vocês viram aí, começou no México e chegou ao Japão rapidinho. Então, não importa onde ele é identificado, se ele é identificado e está sendo muito frequente, significa que ele vai circular bastante.

RM: Como está o risco de contágio dentre os diferentes grupos populacionais?

Dra. Marta: Como esse é um novo vírus, todos estão suscetíveis. O que é característico das pandemias é o maior acometimento de adultos jovens, diferentemente das gripes sazonais. Já os grupos de risco, como os imunodeprimidos, cardiopatas, pneumopatas, idosos e crianças possuem maior chance de desenvolver uma doença grave ao entrar em contato com o vírus, mas também os adultos jovens podem desenvolver uma doença grave, com maior atenção às mulheres grávidas. Que é o que está sendo observado.

RM: É possível uma pessoa entrar em contato com esse vírus e não desenvolver um quadro grave?

Dra. Marta: Sim, como toda doença, esta também pode se manifestar de maneiras diferentes em cada pessoa. Pode-se adquirir a influenza A e desenvolver leves sintomas ou uma doença grave. Possivelmente quem adquiriu a doença ficará imune, o que será confirmado após estudos.

RM: Alguns grupos de pessoas se uniam em locais fechados com a intenção de entrar em contato com o vírus. Uma das ideais desses grupos era se imunizar antes que ocorra mutação no vírus e ele se torne mais virulento.

Dra. Marta: Essa situação não é nova. Nos EUA havia uma prática que se chamava Festa da Catapora. As mães locais organizavam uma festa para que os filhos entrassem em contato com outra criança infectada. Mas essa prática, assim como as festas que você citou, é muito perigosa, já que alguns dos participantes poderão desenvolver um quadro muito grave e morrer.

RM: Qual o procedimento do Hospital das Clínicas ao receber um paciente com suspeita da gripe $\mathrm{H} 1 \mathrm{~N} 1$ ?

Dra. Marta: Nós do HC, um hospital de referência, nos comprometemos com internar os casos graves que chegarem com insuficiência respiratória. Os indivíduos graves serão tratados na UTI daqui.

RM: Qual o papel do Instituto Adolfo Lutz?

Dra. Marta: Ele é responsável por fazer os procedimentos diagnósticos, já o Butantã, em São Paulo, trabalha com a produção de vacinas. 